\title{
Responsible Environmental Behaviour: An Observational Study of Packaging of Household Generated Waste for Disposal in Port Harcourt, Nigeria \\ Rim-Rukeh Akpofure*
}

Department of Environmental Management \& Toxicology, College of Science, Federal University of Petroleum Resources, Delta State, Nigeria

\begin{abstract}
Improper waste disposal by one individual affects the entire citizenry. Government had advocated for the proper packaging of domestic waste at the household levels for the purposes of protecting the waste material being release into the environment especially during transit and for ease of collection of waste material especially at the waste collection centres. This paper assessed the practice of packaging household generated waste for disposal at Government designated waste collection centres. An observational (with non-participation) method was adopted. A total of 854 observations were made within the study period. A score of 100 marks was alloted to correct waste disposal practice and wrong waste disposal practices was given a score of 0 marks. Findings indicate that the behaviour of individuals to always properly package their household generated waste for disposal at designated collection points/centers are low. This study recommended increased awareness in creating positive environmental behaviour amongst citizens.
\end{abstract}

Keywords: Houeshold waste; Responsible environmental behavior; Waste disposal; Packaging of domestic waste; Waste collection centres

\section{Introduction}

Continuously increasing quality of life and high rates of resource consumption have had an unintended and negative impact on the urban environment by way of the generation of wastes far beyond the handling and treatment capacities of urban government and agencies. Cities especially in Africa are now facing serious problems of high volumes of wastes, characterized by inadequate disposal technologies/ methodologies, rising costs of management, and adverse impact of wastes on the environment. Globally, millions of tons of municipal solid waste are generated every day. Urban waste management is drawing increasing attention, as it can easily be observed that too much garbage is lying uncollected in the streets, causing inconvenience, environmental pollution, and posing a public health risk [1,2].

Inadequate and improper sanitation and poor solid waste management remains two of the main transmitters of diseases in the world's developing countries [1]. Venkateshwaran [3] attributed the outbreak of plague in Surat in India to the uncontrolled fermentation of waste which created conditions favourable to the breeding and growth of rodents and insects that acted as vectors of diseases. A similar study by WHO [4] observed in 1994 that 616,960 cases of cholera resulting in 4,389 deaths were reported in Angola, the Democratic Republic of the Congo, Malawi, Mozambique and Tanzania. At least 600 deaths occurred out of 171,000 cases of dysentery in Malawi, Mozambique and Zimbabowe [5]. This is linked to the fact that 80 percent of urban solid wastes are disposed of by dumping in open spaces. Research studies also suggested contamination of ground water by diseases causing organisms from water seeping through dumps is likely to include the viruses of hepatitis, poliomyelitis and gastroenteritis. Thus such water contamination may have long run health effects apart from the more immediate ones like dysentery and cholera [6].

In Nigeria, evidence abounds, where ordinary citizens have arbitrarily dumped their solid waste refuse into gutters or open drains (even when hoppers or waste bins are provided). For example, in a study carried out in Lagos in 2005 to assess the success of Lagos Environmental Sanitation Authority and Malaria Control Project in six communities of Surulere, Ajeromi and Mushin Local Government Areas, about 70 percent of the sampled 1403 respondents confirmed that they often dumped their refuse inside the gutters [7].

In order to curb the mountain of environmental problems, especially urban solid waste management that is currently threatening the quality of life in most developing countries, environmentalists through various conferences have advocated for a shift from technical and scientific solution to the modifications of human behavioural pattern towards the environment [8-11]. Substantial changes in human behavior will be needed in order to transition into a sustainable society [12]. Developing responsible environmental behaviour has become one of the tasks of environmentalist's most especially environmental educators. Several approaches that can be employed to promote environmentally responsible behaviour have been advocated [13-15].

Proper waste management is a public benefit and obligation. Improper waste disposal by one individual affects the entire citizenry, so, as a policy, countries have tasked every individual, establishment or institution to contribute significantly to the process of keeping their communities and environment clean [16]. The Government of Rivers State through its agency on waste management (Rivers State Environmental Sanitation Authority) have advocated for the proper packaging of domestic waste at the household levels for the purposes of protecting the waste material being release into the environment especially during transit and for ease of collection of waste material especially at the waste collection centres. Proper packaging of waste materials implies the use of black cellophane for collection and tied at its tip before taking it to the waste collection centres. The aim and objective of the study was to assess the practice of packaging household generated waste for disposal at Government designated waste collection

*Corresponding author: Rim-Rukesh Akpofure, Department of Environmental Management \& Toxicology, College of Science, Federal University of Petroleum Resources, P.M.B. 1221, Effurun, Delta State, Nigeria, Tel:+[555] 555-5555; E-mail: akpofure.rim@fupre.edu.ng or arimrukeh@yahoo.co.uk

Received April 03, 2017; Accepted May 02, 2018; Published May 09, 2018

Citation: Akpofure RR (2018) Responsible Environmental Behaviour: An Observational Study of Packaging of Household Generated Waste for Disposal in Port Harcourt, Nigeria. Int J Waste Resour 8: 339. doi: 10.4172/2252-5211.1000339

Copyright: (c) 2018 Akpofure RR. This is an open-access article distributed under the terms of the Creative Commons Attribution License, which permits unrestricted use, distribution, and reproduction in any medium, provided the original author and source are credited. 
centres in Port Harcourt, Rivers State.

\section{Responsible environmental behaviour}

What then do we really mean when we talk about responsible environmental behaviour. Cottrell and Graefe [17] defined responsible environmental behaviour (REB) as actions taken by individuals or a group of individuals to do what is right to protect the environment. Kurtycz [14] gave a practical definition of REB as the whole of actions of an individual within the society, that take into account, in a conscious way, the perennial and harmonious relationship between these actions and the environment. According to Emmons [18], REB is a self-determined behaviour aimed at consciously influencing the environment positively.

From these definitions REB is targeted at the whole of actions taken as distinct from positive environmental actions that is aimed at isolated actions. Responsible environmental behaviour is concerned with doing what is right. But to do what is right is not easy if one does not know the value scale of what is right and what is wrong.

\section{Materials and Methods}

\section{Study area}

Port Harcourt, the study area (Figure 1) is the capital of Rivers State with area coverage of about $12,000 \mathrm{Ha}$ [19]. The population of the area is estimated at $1,200,000$ million using a projection of 2.8 percent growth rate of the 1991 population figure [20]. The area is an important industrial and commercial center with a number of flourishing industries such as National Fertilizer Company of Nigeria (NAFCON), Eleme Petrochemicals Company Limited, Port Harcourt Refining Company Limited etc. The presence of potential energy from oil and natural gas has made Port Harcourt to become one of Nigeria's most important industrial cities. Previous study of the meteorology of the area [21] reveals the average atmospheric temperature to be $25.50^{\circ} \mathrm{C}$ in the rainy season and $30.0^{\circ} \mathrm{C}$ in the dry season. The daily relative humidity values range from 55.50 percent in dry season to 96.00 percent in rainy season. Rainfall in the area averages $2500 \mathrm{~mm}$ annually. The rainfall pattern shows two identifiable seasons; the rainy season (April to October) and the relatively short dry season (November to March).

Average daily waste (refuse) generated in Port Harcourt ranged between 900 to 1350 metric tons [22]. The agency charged with the responsibility of solid waste management in Port Harcourt is Rivers State Environmental Sanitation Authority (RSESA). The agency created refuse collection centers / points within the metropolis and evacuate it to designated government approved dumpsites. Composition of waste generated include; Garbage (41\%), paper and plastics $(35 \%)$, scrap metal and glass (15\%), construction waste (4\%), sludge (3\%) and expired chemical wastes and drugs (2\%) [22].

\section{Current solid waste management practice in the study area}

The agency charged with the responsibility of the management of urban solid waste in the study area is Rivers State Environmental Sanitation Authority (RSESA). For the purpose of collection, transfer and management of solid waste within Port Harcourt metropolis, the state is divided into 65 zones. In each zone, there are about 10 designated centers (usually located at street junction or by the sides of the roads) and in most cases, there are no bins or hoppers, the wastes are left on the ground. Each zone is served by a collection contractor which comprises of 1 driver and between 10 to 15 workers. Each collection contractor has a 10 cubic metre open truck. Collection is done daily from $6.00 \mathrm{pm}$ to $6.00 \mathrm{am}$.

\section{Methodology}

Within the study area, ten [10] waste collection centres were randomly selected for the study (Table 1). A research assistant was appointed to observe disposal practices of residents (without his knowledge) on random days throughout the weeks of May and June, 2017, between the hours of 11 am and $2 \mathrm{pm}$. An observational checklist was designed to observe the practice of domestic wastes disposal at the waste collection centres (Table 2). The checklist is made up of six [6] items to which scores were alloted. Self-made scoring system was used to categorize the residents as whether they follow the correct practice, partially correct practice or the incorrect practice. A score of 100 marks was alloted to correct waste disposal practice and wrong waste disposal practices was given a score of 0 marks. However, partially correct practice was give a score of between 30 and 50 marks. This method of study is consistent with previous one [23].

\section{Results and Discussion}

A total of 854 observations were made across the waste collection sites as presented in Table 3. In terms of gender, 854 of the residents were males $(133=15.57 \%)$ and females $(721=84.43 \%)$. This implies that a reasonable number of waste managers at the household levels are females. It has been hypothesized that women demonstrate greater enthusiasm in environmental issues than men $[24,25]$.

The aim and objective of the study was to assess the practice of packaging household generated waste for disposal at Government designated waste collection centres in Port Harcourt, Rivers State. The frequency and percentage distribution of observation reveals that $36.07 \%$ of the residents were found to follow the correct practices of proper domestic waste packaging while the rest which represents $63.93 \%$ were ignorant on all counts regarding the proper practices. The finding does imply that the practice of the norm or behaviour of individuals to always properly package their household generated waste dispose in designated collection points/centers are low. Similar observations have been reported [26].

\section{The role of awareness in promoting responsible environmental behaviour}

There is a growing perception that inadequate education about the importance of proper sanitation account for poor waste management practices [27]. Other factors accounting for this situation are poor attitudes and lack of concern about environmental issues, high levels of poverty and misguided waste disposal practices [26].

The importance of improving awareness of residents as it concerns proper waste packaging for ease disposal cannot be overemphasized. This study relied on the role of awareness in creating positive environmental behaviour amongst citizens. The role of awareness in influencing the adoption of responsible environmental behaviour dates back to early 1990s, when in Mexico, the need to manage the problem of water shortage arose [14]. It was clear then, that in order to develop methodologies to deal with water environmental problems, it was necessary to carry along the populace using proper awareness strategies. Awareness can help individuals to understand the interaction between resources (natural) and the environment.

Awareness from the perspective of this paper goes beyond the mere provision of information by technical means (telephone, print and electronic media). Awareness as used in this paper is a way of 
Citation: Akpofure RR (2018) Responsible Environmental Behaviour: An Observational Study of Packaging of Household Generated Waste for Disposal in Port Harcourt, Nigeria. Int J Waste Resour 8: 339. doi: 10.4172/2252-5211.1000339

Page 3 of 5

\begin{tabular}{|c|c|c|c|}
\hline \multirow{2}{*}{ S/No } & \multirow{2}{*}{ Waste collection centres } & \multicolumn{2}{|c|}{ Geographical coordinates } \\
\hline & & Northing & Easting \\
\hline 1 & Trans-woji road by Elelewo bridge head & $4^{\circ} 47^{\prime} 33^{\prime \prime}$ & $7^{\circ} 42^{\prime} 31^{\prime \prime}$ \\
\hline 2 & Mile 1 market/mile 1 police station along Ikwerre road & $4^{\circ} 47^{\prime} 24^{\prime \prime}$ & $6^{\circ} 59^{\prime} 36^{\prime \prime}$ \\
\hline 3 & Mile 3 market along Ikwerre road & $4^{\circ} 47^{\prime} 002^{\prime \prime}$ & $6^{\circ} 59^{\prime} 52^{\prime \prime}$ \\
\hline 4 & Elelewo road by Elelewo primary school & $4^{\circ} 50^{\prime} 13^{\prime \prime}$ & $7^{\circ} 4^{\prime} 12^{\prime \prime}$ \\
\hline 5 & Woji community road by railway line & $4^{\circ} 44^{\prime} 18^{\prime \prime}$ & $7^{\circ} 07^{\prime} 3^{\prime \prime}$ \\
\hline 6 & Woji community road by llom street Junction & $4^{\circ} 39^{\prime} 16^{\prime \prime}$ & $7^{\circ} 12^{\prime} 17^{\prime \prime}$ \\
\hline 7 & NTA road by Ozumoba community primary health centre & $4^{\circ} 32^{\prime} 07^{\prime \prime}$ & $7^{\circ} 17^{\prime} 29^{\prime \prime}$ \\
\hline 8 & Ordinance road by railway line Elekahia housing estate & $4^{\circ} 41^{\prime} 50^{\prime \prime}$ & $7^{\circ} 21^{\prime} 44^{\prime \prime}$ \\
\hline 9 & East/west road by Okporo Junction & $4^{\circ} 41^{\prime} 46^{\prime \prime}$ & $7^{\circ} 12^{\prime} 09^{\prime \prime}$ \\
\hline 10 & East/west road by vegetable market/Agofure motor park & $4^{\circ} 51^{\prime} 06^{\prime \prime}$ & $7^{\circ} 27^{\prime} 53^{\prime \prime}$ \\
\hline
\end{tabular}

Table 1: Physical description and geographical coordinates of selected waste collection centres.

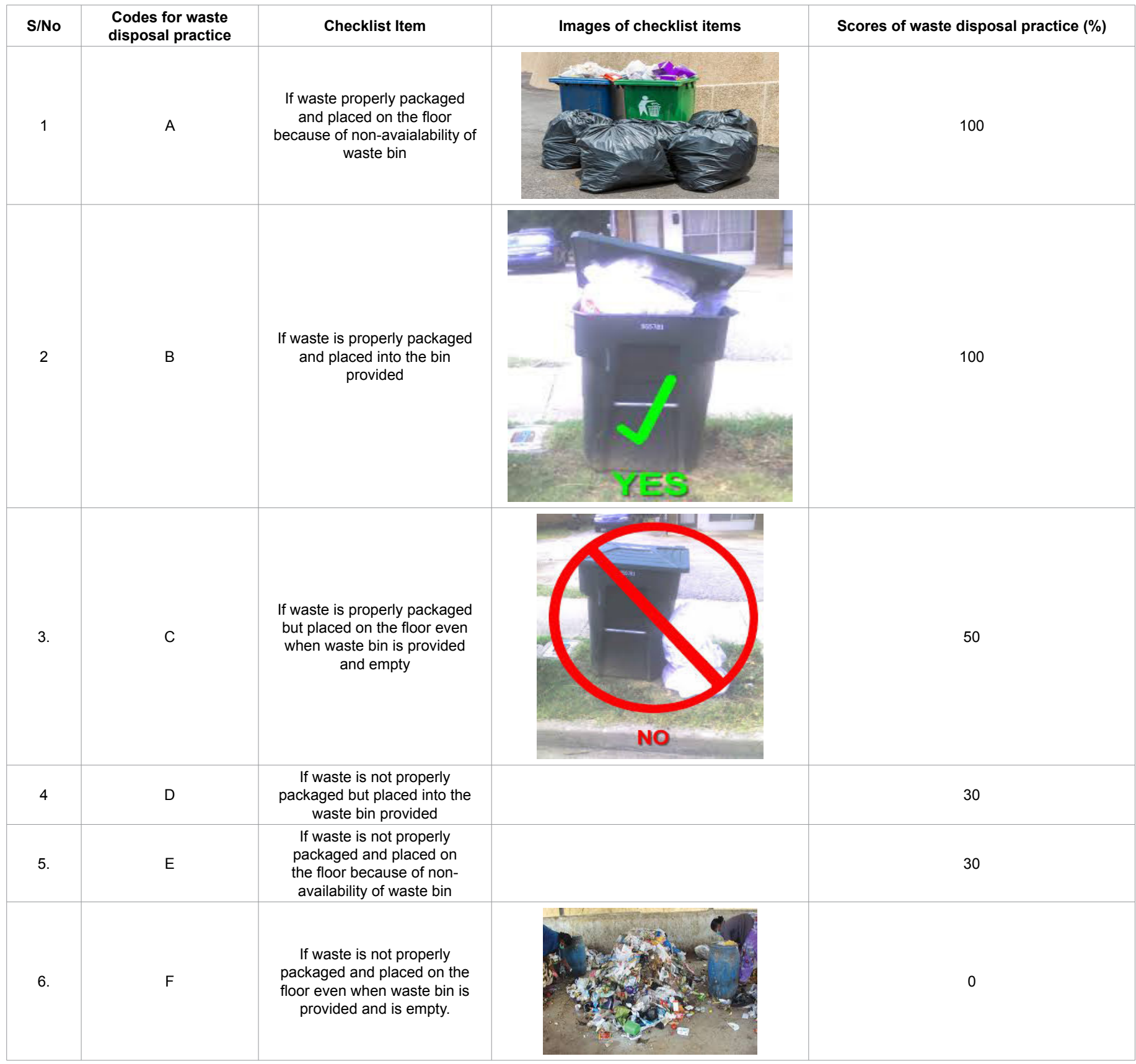

Table 2: Obsevational checklist and scoring. 
Citation: Akpofure RR (2018) Responsible Environmental Behaviour: An Observational Study of Packaging of Household Generated Waste for Disposal in Port Harcourt, Nigeria. Int J Waste Resour 8: 339. doi: 10.4172/2252-5211.1000339

Page 4 of 5

\begin{tabular}{|c|c|c|c|c|c|c|c|c|}
\hline \multirow{2}{*}{ S/No } & \multirow{2}{*}{ Waste collection centres } & \multirow{2}{*}{ No observations } & \multicolumn{6}{|c|}{ Waste disposal practices } \\
\hline & & & A & B & C & D & $\mathbf{E}$ & $\mathbf{F}$ \\
\hline 1 & Trans-woji road by Elelewo bridge head & 54 & 18 & - & - & - & 20 & 16 \\
\hline 2 & Mile 1 market/mile 1 police station along Ikwerre road & 134 & 21 & - & 32 & - & 49 & 32 \\
\hline 3 & Mile 3 market along Ikwerre road & 129 & 7 & - & 27 & - & 54 & 41 \\
\hline 4 & Elelewo road by Elelewo primary school & 56 & 11 & - & - & - & 20 & 25 \\
\hline 5 & Woji community road by railway line & 71 & 29 & - & 12 & - & 13 & 17 \\
\hline 6 & Woji community road by Ilom street Junction & 68 & 23 & - & - & - & 23 & 22 \\
\hline 7 & NTA road by Ozuoba community primary health centre & 73 & 27 & 31 & - & - & 9 & 6 \\
\hline 8 & Ordinance road by railway line Elekhia housing estate & 61 & 16 & & & & 28 & 17 \\
\hline 9 & East/west road by Okporo Junction & 87 & 22 & & & & 34 & 31 \\
\hline 10 & East/west road by vegetable market/Agofure motor park & 121 & 32 & & & & 51 & 38 \\
\hline \multicolumn{2}{|r|}{ Total } & 854 & 206 & 31 & 71 & - & 301 & 245 \\
\hline \multicolumn{2}{|r|}{ Percentages (\%) } & & \multicolumn{3}{|c|}{36.07} & \multicolumn{3}{|c|}{63.93} \\
\hline
\end{tabular}

Table 3: Frequency of observations.

approaching and explaining processes in society. One of the most fundamental defining characteristics of environmental awareness is that which must lead to actions, which result in better environmental outcomes, not simply the accumulation of inert knowledge or impractical skills. This is ultimately the yardstick by which we are able to measure the effectiveness of our efforts in environmental management.

One major objective of environmental awareness is to create responsible environmental behaviour (knowing what is right and doing what is right). Responsible environmental behaviour (REB) can be translated using terms of codes, rules and techniques such that it's dynamics can be understood from awareness perspective. Awareness approaches or strategies allow one to see environmental practices in the context of a system that goes from the definition of the REB to its translation and implementation.

\section{The proposed awareness model}

There is a wealth of evidences to suggest that three categories of factors contribute to REB $[14,28,29]$. These are; (i) cognitive factors which include the levels of understanding of environmental issues and how to take action, (ii) psycho-social factors that include attitude towards environmental issues, and sense of responsibility to do something to reduce environmental degradation and (iii) demographic factors such as gender and the level of educational attainment.

The central assumption in this study is the need to understand the way people think before we can effectively create awareness information for responsible environmental behaviour. From the study, it is evident that lack of awareness, the low capacity to act and acceptance of the norm of sound environmental practices are responsible for the observed behaviour. I therefore developed awareness communication model from the standpoint of this study.

This proposed model is based on the following principles:

- Definition of the problem and the need to solve the problem.

- Definition of responsible environmental behaviour.

- Translate REB to the interests and perception of the individual.

- Kind of communication useful to creating the necessary awareness.

The proposed awareness model is illustrated in Figure 2.

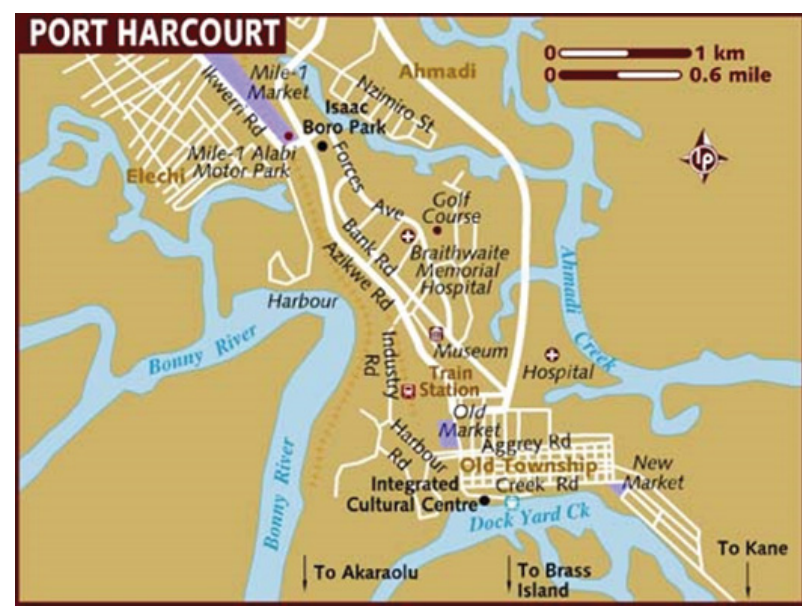

Figure 1: Map of Port Harcourt metropolis.

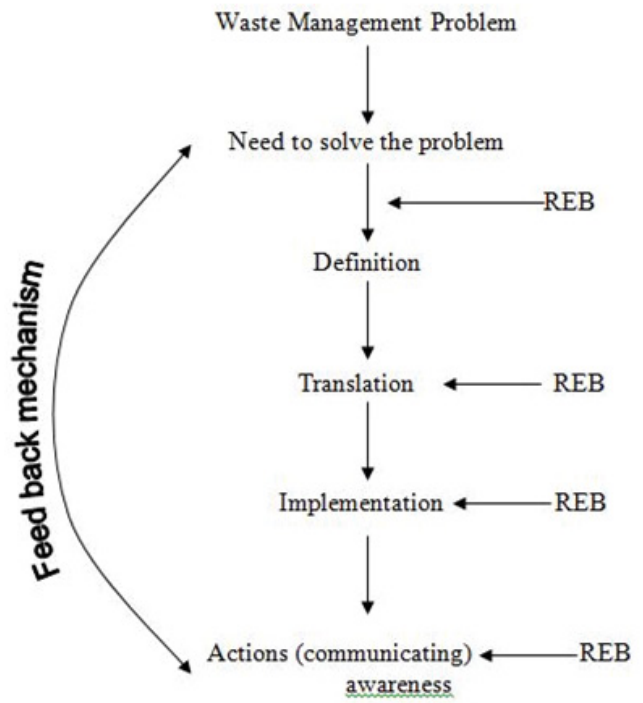

Figure 2: Awareness communication model.

\section{Conclusion}

In the study area, poor urban solid waste management is currently 
Citation: Akpofure RR (2018) Responsible Environmental Behaviour: An Observational Study of Packaging of Household Generated Waste for Disposal in Port Harcourt, Nigeria. Int J Waste Resour 8: 339. doi: 10.4172/2252-5211.1000339

Page 5 of 5

threatening the quality of life.

Improper waste disposal by one individual affects the entire citizenry and hence the Government of Rivers State through its agency on waste management (Rivers State Environmental Sanitation Authority) have advocated for the proper packaging of domestic waste at the household levels for the purposes of protecting the waste material being release into the environment especially during transit and for ease of collection of waste material at the waste collection centres. Proper packaging of waste materials implies the use of black cellophane for collection and tied at its tip before taking it to the waste collection centres. The aim and objective of the study was to assess the practice of packaging household generated waste for disposal at Government designated waste collection centres in Port Harcourt, Rivers State using the non-participatory observational approach.

A total of 854 obervations were made. Of the total obervations, 308 which represents $36.07 \%$ were found to follow the correct practices of proper domestic waste packaging while the rest (546) which represents $63.93 \%$ were ignorant on all counts regarding the proper practices. Generally, the practice of the norm or behaviour of individuals to always properly package their household generated waste dispose in designated collection points/centers are low. From the study, it is evident that lack of awareness, the low capacity to act and acceptance of the norm of sound environmental practices are responsible for the observed behaviour.

- Conclusively, the results of the study indicate that environmental behaviour has a plethora of determinants that can be changed or influenced by adequate awareness. Thus the following recommendation needs to be implemented: (i) strict implementation of urban solid waste policy, (ii) conducting the awareness programme for major waste generators at the household levels (women), (iii) organizing continuous awareness programme amongst the populace and (iv) the development of a communiciation model that suggest that is based on the following principles:

- Definition of the problem and the need to solve the problem.

- Definition of responsible environmental behavior.

- Translate REB to the interests and perception of the individual.

- Kind of communication useful to creating the necessary awareness.

\section{References}

1. Adelegan JA (2001) Urban Solid Waste Generation Forecast and Management in Nigeria. International Conference on Conservation Issues and Innovative Initiatives for Sustainablilty of the Niger Delta Wetlands, International Institute for Environmental Research, Benin City, Nigeria.

2. Rim-Rukeh A (2014) An Assessment of the Contribution of Municipal Solid Waste Dump Sites Fire to Atmospheric Pollution. Open J Air Pollution 3: 53-60.

3. Venkateswaran S (1994) The Wealth of Waste Pickers, Solid Waste and Urban Development. Friedrich Ebert Stiftung, New Delhi.

4. World Health Organization (1998) Environmental Matters - Strategy on Sanitation for High Risk Communities. Report by the Director General to the Executive Board
5. Holloway JP (1995) Living Near a Refuse Disposal Site. Waste Recycling 8: 21-32.

6. Garrod G, Willis K (1998) Estimating lost amenity due to landfill waste disposal. Resour Conserva Recycling 22: 83-95.

7. https://www.jica.go.jp/nigeria/english/activities/health02.html

8. http://www.un.org/ga/search/view_doc.asp?symbol=A/CONF.48/14/REV.1

9. https://sustainabledevelopment.un.org/content/documents/Agenda21.pdf

10. The UK Biodiversity Action Plan (1994) Sustainable Development: The UK Strategy.

11. No Authors Listed (2002) Achieving a Better Quality of Life: Review of Progress Towards Sustainable Development. Department for Environment, Food and Rural Affairs, UK.

12. Spence A, Pidgeon N (2010) Psychology, Climate Change \& Sustainable Behavior. Environment 51: 8-18.

13. Oskamp S (2002) Environmentally Responsible Behaviour: Teaching and Promoting it Effectively. Analyses Social issues public policy 2: 173-182.

14. Kurtycz A (2005) Understanding Environmental Behavoiur Change Through Communication: A New Perspective of Environmental Education. Int J Environ Sustain Develop 4: 35-46.

15. Ayodele JO (2005) Community Based Approach as a Mechanism for Effective Environmental Sanitation (garbage control) in Nigeria Cities. A paper presented at the 13th Conference of Environmental Behaviour Association of Nigeria held at University of Benin, Benin City.

16. Bitner MJ (1992) Servicescapes: The Impact of Physical Surroundings on Customers and Employees. J Marketing 56: 57-71.

17. Cottrell S, Graefe AR (1997) Testing a Conceptual Frame work of Responsible Environmental Behaviour. J Environ Educa 29: 17-28.

18. Emmons KM (1997) Perspectives on Environmental Action: Reflection and Revision through Practical Experience. J Environ Education 29: 34-44.

19. Niger Delta Development Commission (2003) Environment and Hydrology Study Report.

20. National Population Commission (1991) Final Results of Rivers State.

21. Gobo AE (1998) Meteorology and Man's Environment. African-link Books, Ibadan. pp: 101-127.

22. Rivers State Environmental Sanitation Authority (2005) Environment and You. A Publication of Rivers State Government

23. Hemavathy V, Bhaskaran G, Kharphuli J (2014) A Descriptive Study to Assess the Practice of Biomedical Waste Management among Staff Nurses in Selected Hospitals, Chennai. Int J Sci Resear 5: 1281-1283.

24. Gifford R, Hay R, Boros K (1982) Individual Differences in Environmenta Attitudes. J Environ Education 14: 19-23.

25. Hampel B, Boldero J, Holdsworth R (1996) Gender Patterns in Environmental Consciousness among Adolescents. Australian and New Zealand Journal of Sociology 32: 211-218.

26. Guagnano GA, Stern PC, Dietz T (1995) Influences on attitude-behavio relationships: a natural experiment with curbside recycling. Envrion Behav 27: 699-718.

27. Obirih Opareh, Post J (2002) Quality assessment of public and private modes of solid waste collection in Accra, Ghana. Habitat International 26: 95-112.

28. Hunger ford L, Volk T (1990) Changing Learner Behaviour through Environmental Education. J Environ Education 21: 8-21.

29. Hines JM, Hungerford HR, Tomera AN (1987) Analysis and Synthesis of Research on Responsible Environmental Behaviour: a Meta-Analysis. J Environ Education 18: 1-8 